\title{
Lincoln's “Unfathomable Sorrow": Vinnie Ream, Sculptural Realism, and the Cultural Work of Sympathy in Nineteenth-Century America
}

Gregory Tomso

\author{
(2) OpenEdition \\ Journals \\ Édition électronique \\ URL : https://journals.openedition.org/ejas/9139 \\ DOI : 10.4000/ejas.9139 \\ ISSN : 1991-9336 \\ Éditeur \\ European Association for American Studies
}

Référence électronique

Gregory Tomso, «Lincoln's "Unfathomable Sorrow": Vinnie Ream, Sculptural Realism, and the Cultural Work of Sympathy in Nineteenth-Century America », European journal of American studies [En ligne], 6-2 | 2011, mis en ligne le 05 avril 2011, consulté le 08 juillet 2021. URL : http:// journals.openedition.org/ejas/9139; DOI : https://doi.org/10.4000/ejas.9139

Ce document a été généré automatiquement le 8 juillet 2021.

Creative Commons License 


\title{
Lincoln's "Unfathomable Sorrow": Vinnie Ream, Sculptural Realism, and the Cultural Work of Sympathy in Nineteenth-Century America
}

\author{
Gregory Tomso
}

I think that history is particularly correct in writing Lincoln down as the man of sorrow. The one great, lasting, all-dominating impression that I have always carried of Lincoln has been that of unfathomable sorrow, and it was this that I tried to put into my statue. --Vinnie Ream ${ }^{1}$

1 On August $30^{\text {th }}, 1866$, Vinnie Ream, at the age of 18 , became the youngest person, and the first woman, to be awarded a commission for a statue by the U.S. government [see figure 1]. The commission was for a life-size marble of Abraham Lincoln to be displayed in the U.S. Capitol building, one of the first of many official tributes to Lincoln that would be made after his assassination the previous year. It would take four and half years before the work would be completed, and during this time Ream became the center of one of the most public and divisive debates ever to take place concerning the relationship between art and American nationhood. Her work, her character, and her sex were relentlessly scrutinized by senators, editorial pundits and newspaper gossips.

2 Some saw Ream as an untutored genius, a self-taught sculptor and daughter of the West who, like Lincoln himself, proved that privilege and social refinement were not requirements for success in the United States. Others saw her as an upstart opportunist who used her strikingly good looks to manipulate powerful middle-aged men, including senators, Civil War generals and at least two presidents, in order to secure government patronage for her art. Though mostly forgotten today, the sensational story of Ream's life and the political controversy surrounding her work has been occasionally re-told 
since her death by a small and heterogeneous group of relatives, professional biographers, art historians, feminists, chroniclers of Civil War history and writers of books for children. Her statue of Lincoln still stands today in Statuary Hall inside the U.S. Capitol. ${ }^{2}$

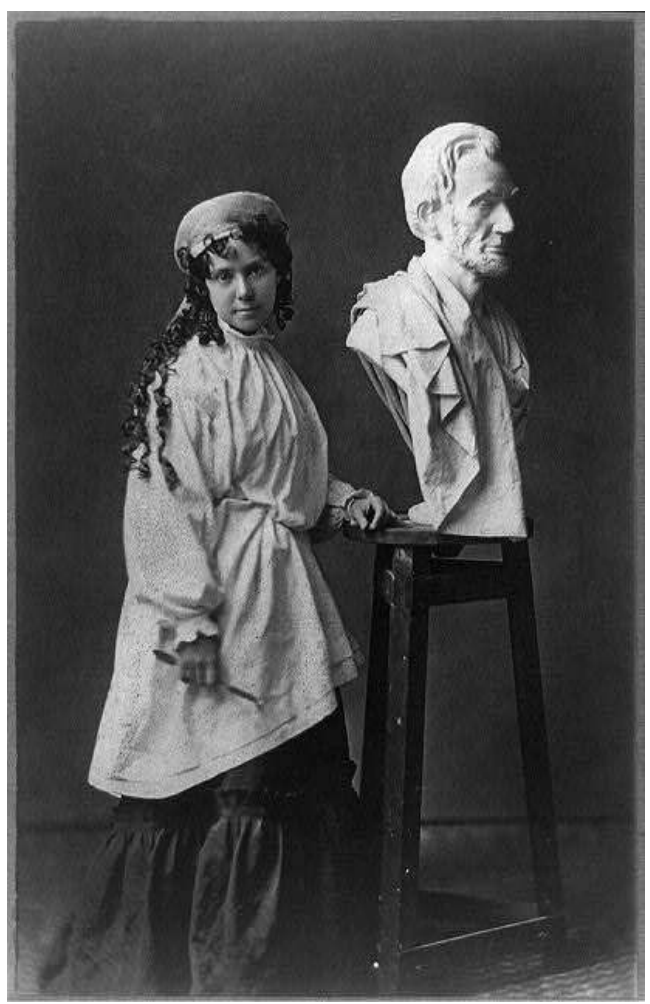

Figure One. Photo of Vinnie Ream posing with one of her early portrait busts of Lincoln. Date unknown, c. 1866.

Library of Congress.

3 As Ream's various biographers have noted, the controversy surrounding her work sometimes had little do with Ream herself. Rather, conflicts developed out of frictions produced by changing conceptions of American nationhood and aesthetics, fueled by sexual chauvinism and regional political rivalries between predominantly Republican, establishment Easterners and predominantly Democratic, populist Westerners. Ream's biggest supporters in the Senate debate about her commission were Democrats, while her fiercest opponent was Charles Sumner of Massachusetts, one of the so-called "Radical Republicans" who opposed Andrew Johnson's lenient Reconstruction policies. In the course of the Senate debate, political tensions of the post-war period merged with arguments about nationalism and aesthetics, particularly in terms of the battle between classicism and realism in American art. Sumner, for example, was not only a foe of Jackson's presidency and plans for Reconstruction; he was also a defender of the classical tradition in American art that championed the work of male sculptors such as Hiram Powers and Horatio Greenough. At stake in Ream's Lincoln, then, was an ideological struggle for the future of American nationhood, played out both in terms of political-policy debates and in terms of aesthetics. Ream's work provided an opportunity for some Democrats, as well as for a handful of Republicans from western states, to champion realism as the most suitable aesthetic style of national art. One defender of the classical old guard would bitingly refer to this realistic aesthetic as the "Wisconsin theory" of American art. ${ }^{3}$ 
Crucial to the success of Ream's realistic portrayal of Lincoln was the role of sympathy. As the epigraph to this essay suggests, sympathy played a vital role in facilitating socially acceptable experiences of nationalist identification. Sympathy, to the exclusion of almost all other responses, both emotional and intellectual, was by far the most prevalent reaction to Ream's statue of Lincoln. Thus, building on the work of Jane Tompkins, Gillian Brown, Lori Merish, Glenn Hendler and others, I would like to look more closely at the "cultural work" of sympathy as it operates in discourses about Ream and her art, focusing on the ideological connections among sympathy, realism, and post-Civil-War American nationalism. ${ }^{4}$

5 Specifically, I argue that the much-touted, life-like features of Ream's statue of Lincoln are not, as her most admiring biographer has claimed, evidence of "man's propensity for naturalism," but signs of a historical shift in the discourses of aesthetics central to what Hendler describes as the subjective process of sentimental, nationalist identification in the nineteenth century. ${ }^{5}$ As the dream of an American Athens, embodied in the classical idealism of Powers and Greenough, gave way to Ream's realism, the powerbrokers of American art and politics did not reject, but intensified and naturalized, the ideological fervor of American nationalism and the forms of sentimental experience crucial to its expression. True to Brown's dictum that "America will be realized in its simulacra," Ream's Lincoln, in its striking verisimilitude, does not so much represent life itself as it instead offers up, for public consumption, a revitalized fantasy of the origin of "Americanness" empirically legible in the face, eyes, tears, hair, hands and "unspeakable sadness" of Lincoln's body. ${ }^{6}$

6 To understand how the realism of Ream's Lincoln plays a part in the creation of this mythical "Americanness," I will return briefly to the national debates about classicism and realism in American public art that found some of their most heated expressions in conversations about Ream's statue. Consider, for example, the writing of California journalist E.G. Waite, who toured Vinnie Ream's studio in the U.S. Capitol. His article on Ream, which appeared in a magazine called the Overland Monthly, nicely sums up the issues:

Of the intelligent lovers of art, I would say there are two classes, having different ideas of what a national statue should be. One would have it idealized, so as to be the beatified presence of the subject, or to represent the spirit of his deeds more, and the actual likeness of the man less. The other would faithfully portray the size, form, clothing, and features of the subject; in fact, a man as nearly as possible as he was, taken at the best period in his history, and in his most favorable mood. One would represent him as a spiritualized incarnation of a great passion or event; while the other would be more intent upon a refined effort of realistic portraiture. ${ }^{7}$

of the American artists who sought to "beatify" and "idealize" their subjects, representing their "spirit" as opposed to their "actual likeness," sculptor Horatio Greenough came most famously to represent these older, classical commitments to creating monumental American art. In the U.S. Senate debate over Ream's commission, Charles Sumner said of Greenough that he was "unquestionably the most accomplished of all in the list of American sculptors. He was a scholar, versed in the languages of antiquity and modern times, who studied the art which he practiced in the literature of every tongue. Of him I never fail to speak in praise." ${ }^{8}$ Even a cursory look at his 1841 statue of George Washington reveals its contrast with Ream's lifelike Lincoln, making clear the aesthetic distance between classicism and realism [see figures two and three]. Sumner, like other defenders of the classical, idealist tradition, fervently believed in 
the possibility of capturing, through art, what Waite calls "a spiritualized incarnation of a great passion or event." The very notion that an artist could somehow create a "spiritualized incarnation" of a subject expresses just the kind of national idealism that Sumner and others would oppose to Ream's seemingly a-spiritual realism. According to this belief, little or nothing of the physical characteristics of a great leader matters to history; nor is it important for the future of a nation for its citizens to remember precisely the minute details of a leader's life or appearance. Instead, what remains valuable is a sort of spiritual residue, an "incarnation" of the timeless and seemingly divine aspects of a leader's being.

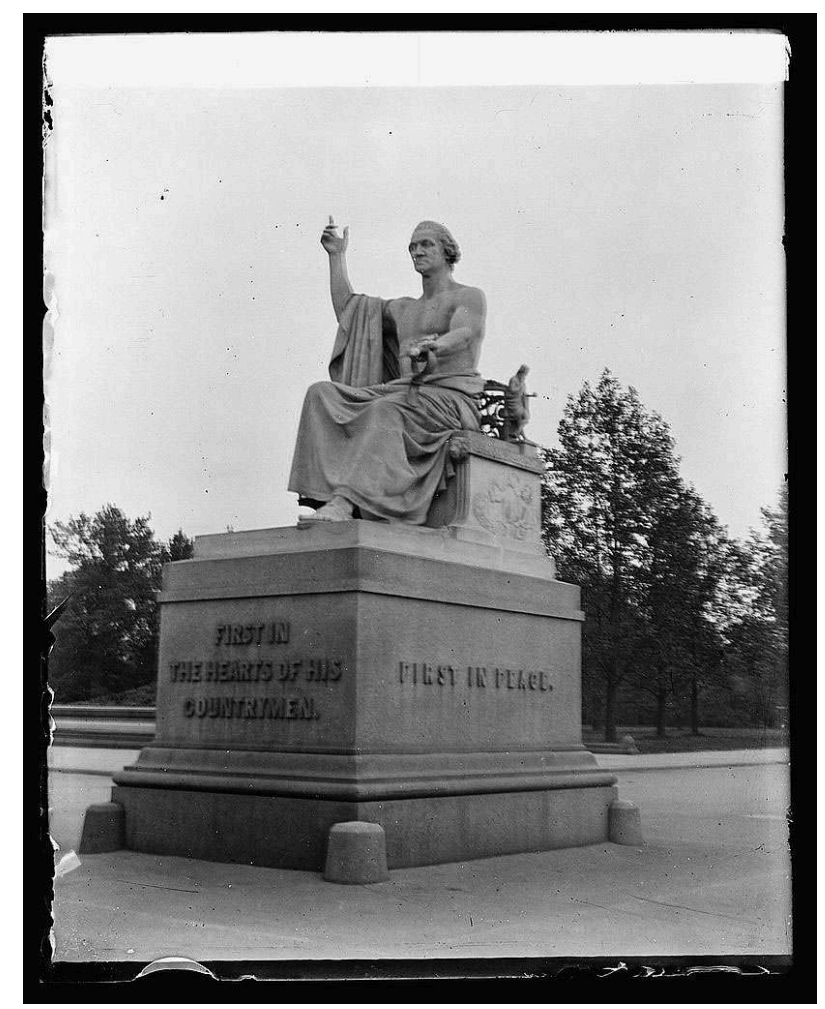

Figure Two. Statue of George Washington by Horatio Greenough. Photograph, Library of Congress. 


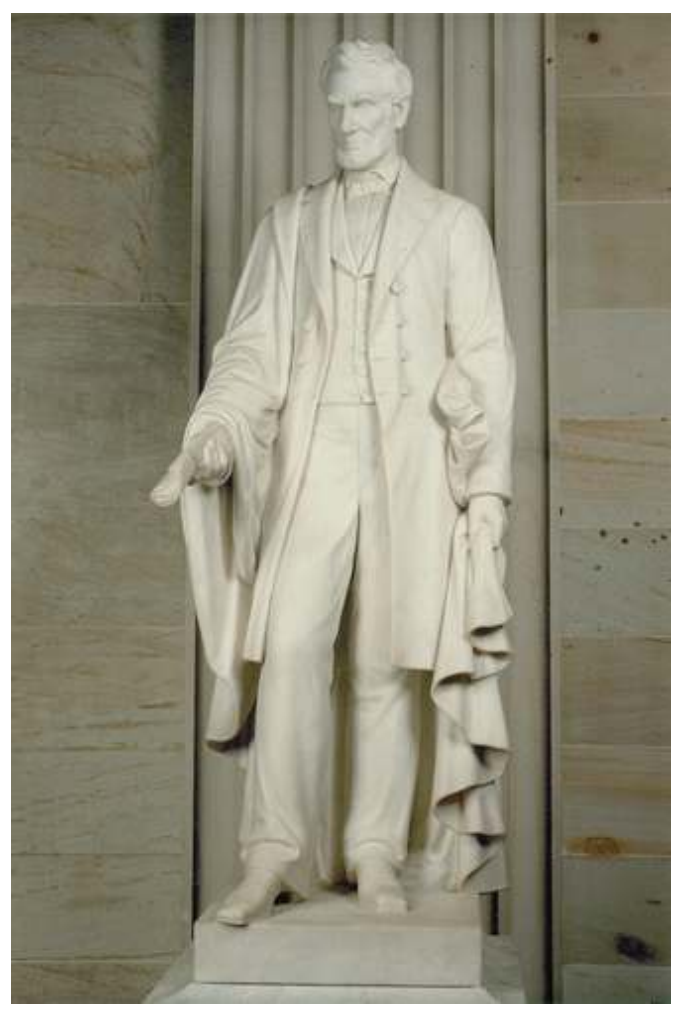

Figure Three. Vinnie Ream's statue of Abraham Lincoln in the U.S. Capitol.

Photograph, Architect of the Capitol.

8 The debate between classicism and realism was, then, far more than merely a disagreement about aesthetics or good taste. At stake was the very possibility of creating an American history. For the idealists, spiritual and therefore historical greatness could not be signified corporeally, through realistic portraiture, but instead rendered through an abstraction, the metonymy, if we return for a moment to Waite, of "a great passion or event." One sees here not only the emphasis on "great passion" or sentiment that became a medium for expressions of nineteenth-century American nationalism, but also the opening to an epistemological problem in the very definition of American history: how, through art, is the history of America to be known, remembered and represented, and what "incarnation" of history is appropriate for, as Waite writes here, a "national statue"? Do physical qualities such as those mentioned by Waite-"size, form, clothing, and features"-have a particular representational, epistemological or spiritual connection to history, passion or event, or are they merely trivialities?

9 If realist details are important, are they more capable than idealism of vouchsafing American nationhood and ensuring the greatness of the republic? These questions help to show how the issue at stake between classical idealism and corporeal realism cannot be boiled down to a war of good taste between a conservative, establishment "old guard" (of which Sumner was the champion) and a more democratic. progressive "new" one. While public opinion on the issue was frequently split along party lines, seeing the issue this way occludes the fact that both points of view are essentially conservative ones: for idealists and realists alike, the central question is one of how best to signify the greatness of the nation during a period of national crisis following Lincoln's death. In fact, as I shall discuss in more detail shortly, even Ream's "realism" 
can be read as a form of idealism, since it is precisely through her intimate rendering of Lincoln's body that the symbolic and spiritual project of postwar nation building can move forward. The underlying question that needs to be addressed here is thus not one of aesthetics or even nationalism, but one of epistemological transformation, given that the proper means to signify national history changes from, in the decades before the Civil War, the abstract rendering of a historical figure as "passion or event" to, in the decade after, the realistic portrayal of that figure in terms "size, form, clothing, and features."

10 To address this question more fully, I examine below two excerpts from the Senate debate about Ream's commission for the Lincoln statue that demonstrate the often circular logics that linked realism to the project of American nation-building. The first is a series of remarks by Senator James McDougall, a Democrat from California:

Where high genius is found, it has been the office of great States to cultivate the development of that genius. Did it not require the wealth and power of princes to develop the genius of Michael Angelo (sic), and Titian and Guido? It was so in past times; it has been so in our time; and we have undertaken to maintain the policy of a great State and to cultivate art, among other things .... All the States of Europe pursue the same policy; and for what? To illustrate their national history and their national qualities; and they have particularly encouraged historical paintings; indeed, a great picture is a history; so is a great statue a history. It is the policy of this Government, a great Government, to cultivate the same talents in our own country. ${ }^{9}$

Note how strikingly McDougall links the production of art to the project of American nation building. Though a Democrat, he imagines himself and his fellow Senators as possessing the "wealth and power of princes" suitable for cultivating high art that will illustrate America's "national history" and "national qualities." One detects here a whiff of American imperialism, a sense of how America must compete on a global scale with its European counterparts so that it might "cultivate the same talents in our own country." Art, McDougall makes clear, is essential to the work of becoming "a great State" and "a great Government," the two most salient political goods that, here at least, appear to be the highest possible aims of statehood. Following this logic, he would go on to argue on Ream's behalf, claiming that she clearly possessed the genius needed for the production of high art.

Though his argument is somewhat circular, he seems to have made his point: "She has had the genius to do it; and it requires genius to do it; and young genius is as good as old genius, and sometimes a little better." ${ }^{10}$ In terms of the epistemological problem of how one best creates an American history, McDougall seems happy to settle the point on ideological grounds. For him, it is clearly through "greatness" that one comes to know what history is, and thus he is able to claim that "a great picture is a history; so is a great statue a history." One need not bother, it seems, with "spiritual incarnations" or physical features: "princes" like himself apparently know both greatness and history when they see it.

As McDougall's remarks illustrate quite well, it was sometimes difficult to articulate in any precise way how it was that a painting or sculpture might actually accomplish the work of establishing American's history and rebuilding the worn-torn nation. The circularity of McDougall's argument about "greatness" parallels an equally circular argument about "truth" and "history" made in the Senate debate by George Franklin Edmunds, a Republican from Vermont who joined Sumner in voting against the Ream 
commission. Though he voiced no objection to Ream's realism, he doubted her ability to make Lincoln real enough:

In this instance we appeal to fidelity to truth to an exact representation of a recent person; and we ask, therefore, for a work which shall not only be true to art, but which shall be true to the truth of history and to the truth of personality in every particular. No statue of Lincoln ought ever to have a place in this Capitol that does not represent him as he was. ${ }^{11}$

The point here, though Edmund's does not spell it out, is that Ream lacks the skill to represent Lincoln "as he was." However, more interesting than his slight to Ream's abilities is how he conflates three different forms of truth. First, Edmunds appeals "to fidelity to truth to an exact representation of a recent person," referring, it seems, to a need for realism or verisimilitude in whatever statue of Lincoln the Senate might commission; second, he notes that the statue must be "true to the truth of history," thereby creating a conceptual link between artistic verisimilitude and history itself, thus coming down, at least on this point, on the side of the realists; and finally, he speaks of the "truth of personality," echoing not the realists, but something of the idealists' notion that a national statue should express intangible qualities, like "great passion." In effect, what Edmunds seems to be doing here, albeit in a confusing way, is using the realists' own arguments against them, suggesting that only someone far more skilled than Vinnie Ream could possibly capture the "truth" in sculpture.

Whatever his intention might have been, however, Edmunds' remarks actually leave a different impression. He repeats the word "truth" or its cognates so often that it begins to take on an almost fetishistic quality, as when he refers to "fidelity to truth" and the need to be "true to the truth" of history. It is here, I argue, that we can begin to see signs of the emerging epistemological associations among realism, nationalism and sentiment. Edmunds creates a discourse of hyper-truthfulness, of hyper-fidelity to life and personality in order to protect "the truth of American history" from the likes of Vinnie Ream and her Democratic supporters. His attack on Ream does not, as Sumner's did, require a defense of idealism or classicism, but a more radical insistence on "fidelity to truth" of all kinds, which here seems to equate to a mandate that art faithfully depict physical features such as "size, form and clothing" that embody both ideal qualities (like personality) and America's rightful place in "history." The fact that his remarks are at once redundant and tautological suggest this very point, if one is willing to read his rhetorical excess around the notion of "truth" as a sign of a deepening, if unconscious, ideological commitment to realism as a signifier of American nationalism and as a sign of an equally unconscious uncertainty about how, precisely, realism could actually make that ideological leap.

With these examples in mind, one can begin to understand the cultural work performed by the sentimental descriptions of Ream's Lincoln that appeared frequently in the popular press and in official comments on her work. While Ream's detractors were vocal in the press, her supporters were far more so, and the mantra of those who championed her was that her Lincoln was the most moving and realistic depiction of "President Martyr" ever sculpted by human hands. In descriptions of the statue's realistic features and of its melancholic affect, it is possible to trace the ideological connections among realism, nationalism and sentiment that underwrote the public's embrace of Ream's art. These appear frequently in the comments people made about her statue of Lincoln, including the following by American painter Miner Kilbourne Kellog in 1869: 
The head and features are forcibly, yet truthfully modelled; the hair boldly managed in flowing masses as by the skill of experience; and the expression of sadness mingled with benevolence is touchingly portrayed, well conceived and appropriate to the expression and meaning of the statue. ... A long circular cloak covers the right shoulder and arm, falls backward off the left, being held partially under the forearm and caught up by the left hand, which grasps its ample folds as if in readiness to cover with the protecting mantle of the Government the defenseless beings who are to receive the inestimable boon of freedom .... ${ }^{12}$

And also these remarks by Republican Senator James W. Patterson of New Hampshire at the unveiling of Ream's Lincoln in the Capitol in 1871:

Sure I am that this is the lean, gaunt figure [of Lincoln], and these the solemn, earnest features we knew and loved so well in those long years of hope and fear through which the nation agonized into its new life of liberty and prosperity. The loose and slouchy dress of the yeoman, which the President only half yielded with reluctance amid the fashions of the capital, has received from the facile hand of sculpture a becoming ease and grace .... The benignant face seems to drop a benediction upon the proclamation of emancipation which he grasps in his hand. A momentary consciousness of the transcendent glory of that god-like act transfigures for the time the whole man, and a heavenly light glows through the fixed sadness of his features. ${ }^{13}$

In both of these descriptions of Ream's Lincoln, we see signs of the discourses of truth and verisimilitude that are important aspects of the success of her sculpture. Kellog, in the first example, notes how "truthfully" Ream has modeled Lincoln, while Patterson, in the second, recognizes in Ream's statue the selfsame "earnest features we knew and loved so well" during Lincoln's presidency. Following the work of both Lori Merish and Bill Brown, we might notice here the important role played by specific objects or "features" in these hyper-realistic descriptions. Lincoln's "long circular cloak," at first objectively described by Kellog, becomes, in the space of one short sentence, "the protecting mantle of the Government," whose "ample folds" help to incorporate the newly freed slaves into the American body politic. In the description by Patterson, the cloak has again morphed into "the loose and slouchy dress of the yeoman," a description that binds Lincoln to the agrarian, democratic ideals of Jefferson and Crèvecoeur.

I propose that we label these descriptions "hyper-realistic" in order to specify how everyday objects like Lincoln's cloak become saturated with symbolic and ideological meaning. However "truthfully modelled," I argue, the realism of Ream's Lincoln is not, in any absolute sense, an objective quality of the sculpture itself, but a mode of signification or a discourse of the real, particular to the era of Reconstruction, whose adherents "loved" Lincoln's features with the sentimental verve indispensable to postwar American nationalism. In moving descriptions of the "flowing masses" of Lincoln's hair, of the ampleness of his cloak, and especially of the "fixed sadness" and "benevolence" of his face, Kellog and Patterson did not simply describe the realness of Ream's work, but invented the very possibility of the "real" as a vehicle for sentimental, and therefore nationalist, experience. It is not difficult to trace the nationalist excesses of their versions of the real, both in the "heavenly light" that glows through Lincoln's form and in the evangelical hope for a "new life of liberty and prosperity" that Patterson easily reads in the statue's "solemn, earnest features." Through the vividness of this effigy of Lincoln, so "touchingly portrayed," Americans, it seems, might begin to heal the war-torn nation through the very act of loving, and by 
taking possession, through a full appreciation of Ream's artistic efforts, of Lincoln's sadness as part of their own experience.

As Merish has described in her book Sentimental Materialism, objects in nineteenthcentury American life became catalysts for varieties of sentimental experience that helped instantiate a particular form of political subjugation, one that she calls sentimental ownership or caretaking, that helped middle-class Americans to ameliorate, yet ultimately disavow, "feelings of political powerlessness." ${ }^{14}$ Sentimental sympathy is not, in Merish's account, a moral value, but a normalizing force particular to free-market capitalism that carefully allows the expression of deep feeling while protecting free-market operations and sustaining middle-class hegemony ${ }^{15}$ Following this line of thought, we might say that those who adored Ream's statue of Lincoln took sentimental possession of their dead President at a time of national crisis, just as countless struggling middle-class characters in nineteenth-century domestic fiction took possession of psychologically comforting and personified objects, including pets, plants, household furnishings and even slaves. One important point to be made here, then, is that the success of Ream's statue was not, as her contemporaries repeatedly claimed, so much a product of artistry as it was of ideology, achieved through shared experiences of sentimental identification. To say so is not to disparage Ream's achievement, but to recognize that realism functions as a technology, a catalyst for a historically specific mode of subjective self-governance that, to borrow a phrase from Amy Kaplan, "contribute[s] to the construction of a cohesive public sphere." ${ }^{16}$ While Kaplan focuses on the illusory nature of such a sphere in her analysis of late nineteenth-century realist fiction, showing how realism ultimately fails to contain class conflict at the end of the century, in Ream's day the problem was, in some senses, more immediate: the political hope expressed in sentimental experience engendered by realism was one of constituting America itself, particularly in the aftermath of civil war.

21 A striking example of this form of sentimental identification can be found in a description of Lincoln's face offered by Republican Senator Matthew Hale Carpenter of Wisconsin, who spoke at the unveiling of Ream's statue in the Capitol Rotunda:

He [Lincoln] was tall and gaunt of figure, wholly destitute of grace, slovenly in dress, with a face sadder than ever was worn by man before; a face which mirrored the melancholy scenes in which he was so prominent an actor; a face which spoke of the trials which made his life almost insupportable, of nights without sleep and days full of trouble, of governmental cares, of personal griefs, of war and the sufferings which war begets, of battlefields, hospitals and graves, of widows and orphans, of a great heart-bleeding, a great soul sorrowful. ${ }^{17}$

Before offering this expansive description of Lincoln's melancholic face, as Ream had captured it in her statue, Carpenter had defended Ream's attempt to represent not a "Jupiter or Apollo," but "Abraham Lincoln as he appeared in the White House ... and as he did on the prairies and in the courtrooms of the West." Hailing Lincoln as "child of nature" whom Ream, herself a product of the Wild West, had managed to capture perfectly, Carpenter here links the experience of sentimental identification with Lincoln's all-encompassing sorrow to the American mythology of "nature" and "prairies," shorthand references to the popular American view of the West as mythical garden, the biblical land of milk and honey. In doing so, he effectively naturalizes the pain of war itself, suggesting that Lincoln's sadness, like America's, is part of the transcendental spirit of nature. As a result, all who view the statue of Lincoln, and 
share in his sorrow, might claim a share in the sentimental project of healing the rift in the nation, of stanching, as it were, America's bleeding heart. The catalyst for this sentimental re-incorporation of the body politic is Lincoln's most striking feature: "a face sadder than ever was worn my man before." For their own part, Americans who survived the Civil War had only to look upon Ream's lifelike statue in order, like Lincoln, to feel more deeply than any people had felt before. To do so, Carpenter implies, is to know the greatness of the nation they had just finished tearing apart. Yet it was Lincoln who would bear the memory of "battlefields, hospitals and graves, of widows and orphans," all of which would be sentimentally contained-that is, both preserved and carefully managed, made palatable for public consumption-in the realistic form of Ream's remarkable statue.

Even the newspaper coverage of the statue's unveiling seems to have participated in this sentimental fantasy of national healing and renewal. In addition to reprinting the remarks of those who spoke at the unveiling ceremony, the reporter who covered the event for Washington, D.C.'s The Evening Star wrote the following day of the crowds who tried to gain entrance to the Capitol to catch a first glimpse of Ream's statue. "The vast assemblage filling the rotunda," the reporter noted, "was made up of every class-the most distinguished, and the lowliest of the nation-and among the most interested spectators of the scene were groups of colored people, who hold Abraham Lincoln in their heart of hearts." ${ }^{18}$ While the facts reported here may certainly have been accurate, what stands out in this account is the utterly democratic nature of the assembled crowd: distinguished and lowly, black and white, all coming together to witness the spectacle of Lincoln's immortalized body.

African Americans receive special notice, not only for their presence, but also for the strength of their sentimental attachment to the dead president. They hold Lincoln in "their heart of hearts," as if the very strength of their love for him binds them closer to America itself. If they are "lowly," as this account implies, they are also "of the nation." If there were any doubt left in readers' minds about the power of such sentimental experience, the reporter dispels it completely by describing how, as the crowd moved into the Rotunda, "the vast hall seemed to rise to an immeasurable height, the various circlets of shaded lights one above another giving an idea of indefinite vastness" as the effigies of former American heroes and presidents painted in the rotunda "looked out from the canvass upon the sad, thoughtful face of Abraham Lincoln." ${ }^{19}$ Lincoln's "sad" face becomes the sentimental locus not only of national identification, as it connects present-day spectators with the luminaries of America's past, but of a renewed sense of American exceptionalism. Like the dome of the rotunda, America seems to rise here to "an immeasurable height," very close, one might say, to heaven itself. America here is also "indefinitely" vast, a sign that that not even civil war can impede the nation's manifest destiny.

While the reading I have sketched out here is only preliminary, my aim has been to document a portion of the cultural work performed by sympathy in mid-nineteenthcentury America. Ream's art, and the lengthy debates surrounding it both in Congress and in newspapers across the United States, possess great value for scholars interested in the history of American nationalism, the work of women artists, the role of affect in the political economy of post-Civil War America and the emergence of realism not just as a dominant postwar aesthetic, but as a powerful catalyst for sentimental identification. Yet only recently has Ream been the subject of critical analysis that 
attempts to locate her work as examples of anything more than exemplary patriotism and the spectacular accomplishments of a child prodigy.

Given the wealth of archival material that Ream's biographers have now made available to scholars, it seems that Ream is long overdue for more serious scholarly consideration. Indeed, the history of her very reception in American history could be a scholarly topic in its own right: beloved by children's writers, the Daughters of the American Revolution, and Civil War historians, Ream became, in the second half of the twentieth century, something of a conservative American icon..$^{20}$ Glenn V. Sherwood, whose 1997 biography helped retrieve Ream from obscurity, has gone so far as to claim that Ream's story may have a "special spiritual meaning" for America and that her accomplishments may be signs of an "overruling Providence" guiding American history. Rather than looking for signs of God's favor in the intricate lines and lifelike shapes of Ream's sculpture, it may benefit present-day scholars to read the history of her reception in American letters as an extension, or survival, of the sentimental nationalism elicited by her work in her own time. The cultural work of Ream's life and art continues to exert its influence today, even if its effects remain more imaginary than real.

\section{NOTES}

1. Vinnie Ream, "Personal Recollections of Lincoln . . . ," Sunday Star, February 9, 1913, Washington, D.C. Reprinted in R.L. Hoxie, Vinnie Ream (Washington, D.C.: Gibson Brothers, 1908) 59-60. Note that the date of re-publication in the collection titled Vinnie Ream is 1908, but that the article cited was published in 1913. The article was obviously added to a later edition of the original 1908 volume, but only the original publication date of 1908 is given.

2. Ream's most exhaustive biographer is Glenn V. Sherwood. See A Labor of Love: The Life and Art of Vinnie Ream (Hygiene, CO: Sunshine Press Publications, 1997). See also Edward S. Cooper, Vinnie Ream: An American Sculptor (Chicago: Academy Chicago Publishers, 2004). For recent critical discussions of Ream's life and work, see: Melissa Dabakis, "Sculpting Lincoln: Vinnie Ream, Sarah Fisher Ames, and the Equal Rights Movement," American Art 22 (Spring 2008): 79-101; and Kirk Savage, “Vinnie Ream's Lincoln (1871): The Sexual Politics of a Sculptor's Studio," American Pantheon: Sculptural and Artistic Decoration of the United States Capitol, eds. Donald R. Kennon and Thomas P. Somma (Athens, Ohio: Ohio University Press, for the U.S. Capitol Historical Society, 2004) 160-175; and Carmen A. Prioli, “' 'Wonder Girl from the West' ": Vinnie Ream and the Congressional Statue of Abraham Lincoln," Journal of American Culture 12 (2004) 1-20.

3. For more on the "Wisconsin theory," see Prioli 14 and note 67.

4. The phrase "cultural work" comes from Jane Tompkins, Sensational Designs: The Cultural Work of American Fiction, 1790-1860 (New York: Oxford UP, 1985). For more recent work on sentimentalism in American literature, in the vein I am interested in here, see Glenn Hendler, PublicSentiments: Structures of Feeling in Nineteenth-Century American Literature (Chapel Hill: North Carolina UP, 2001); Gillian Brown, Domestic Individualism: Imagining Self in Nineteenth-Century America (Berkeley: University of California Press, 1990); and Lori Merish, Sentimental Materialism: Gender, Commodity Culture, and Nineteenth-Century American Literature (Durham, N.C.: Duke University Press, 2000).

5. Sherwood 340 . 
6. The phrase from Brown comes from "Fables and Forming of Americans," Modern Fiction Studies 43 (1997) 115-143. The text cited comes from page 115. The phrase "unspeakable sadness" comes from John Hay, "Life in the White House in the Time of Lincoln," Century Illustrated Monthly Magazine (November 1890): 33-37. I learned of the reference from Sherwood, 26.

7. E.G. Waite, "Vinnie Ream," Overland Monthly (August 1871): 144-150. Publicly accessible electronically in the Making of America database, < http://quod.lib.umich.edu/m/moagrp/>.

8. The full text of the debate is reprinted in Sherwood. The passage quote appears on page 59. The full text of the debate is also available online as part of a web site published in conjunction with Sherwood's biography. See <http://www.vinnieream.com/debate.htm>

9. Sherwood 52. For more on the debate, see note 7 above.

10. Sherwood 52

11. Sherwood 62. For more on the debate, see note 7 above.

12. Reprinted in R.L. Hoxie, Vinnie Ream, 5. Kellog's comments were first published "in the local papers" around Washington, D.C., in February, 1869.

13. Reprinted in Sherwood 163-164 and R.L. Hoxie, Vinnie Ream 16-28 . The original speeches were first published in The Evening Star, Washington, D.C., January 26, 1871.

14. Merish 4, 5 .

15. Merish 4.

16. Amy Kaplan, The Social Construction of American Realism (Chicago: University of Chicago Press, 1988) 9.

17. Sherwood 168 and R.L. Hoxie, 27.

18. Sherwood 155 and R.L. Hoxie 17.

19. Sherwood 155 and R.L. Hoxie 17.

20. See, for example, Harold Holzer and Lloyd Ostendorf, "Vinnie Ream: The Girl Who Sculpted President Lincoln," Civil War Times, 21:3 (1982) 26-33 and Cecile Ream DeBirny, "Vinnie Ream," Daughters of the American Revolution Magazine 107 (February 1973): 89-96. Children's books about Vinnie Ream include: Gordon Langley Hall, Vinnie Ream: The Story of the Girl who Sculpted Lincoln (New York: Holt, Rinehart and Winston, 1963); Dawn FitzGerald, Vinnie and Abraham, 2006, illus. Catherine Stock (Watertown, Mass.: Charlesbridge, 2009); and Maureen Stack Sappey, Letters from Vinnie (Honesdale, Pa.: Front Street/Boyds Mills Press, 1995).

INDEX

Keywords : sentimentality, sympathy, sculpture, realism, American art, aesthetics, nineteenth century, Vinnie Ream Hoxie, Abraham Lincoln 